\title{
Exploration of the Influence of Learning ELPSA (Experiences, Language, Pictures, Symbols, and Applications) on the Understanding of Mathematical Concepts
}

\author{
Herwandi $^{1}$, Andi Kaharuddin ${ }^{2}$ \\ Mathematics Education Faculty of Teacher Training and Education, Lakidende University of Unaaha \\ wandiherwandi2194@gmail.com¹ andikaharuddinunilaki@gmail.com²
}

\begin{abstract}
The ability of students to understand the concept of learning varies, it is very necessary to know the level of understanding of students' concepts in learning mathematics, so that it becomes a rationale in determining the appropriate learning approach. This study aims to determine the effect learning approach of the ELPSA eighth grade students of SMP Negeri 6 Makassar. The type of research used is experimental research. The design of this research is the One-Group Pretest-Posttest Design. The population in this study were students of class VIII SMP Negeri 6 Makassar in the 2019/2020 academic year and the research sample was determined by the Cluster Random Sampling technique. The instrument in this study was an essay test on understanding mathematical concepts. The data analysis used was descriptive and inferential. The descriptive research results show that there is an increase in understanding of the mathematical concept after the application of the ELPSA learning approach; the score of concept understanding after the application of the ELPSA learning approach met the completeness criteria, namely more than 80; and completeness of students' conceptual understanding after being applied classical ELPSA learning approach is $97 \%$ complete. The inferential hypothesis testing results show that the application of the ELPSA learning approach affects the understanding of mathematical concepts in class VIII students of SMP Negeri 6 Makassar.
\end{abstract}

\section{Keywords: ELPSA Approach; Mathematical Concept Understanding}

\section{INTRODUCTION}

The development of science and technology which is increasing rapidly has implications for changes in the world of education. The world of education is closely related to students as learners who are the main subjects in education. According to (Umar, et all, 2020) students must be equipped with knowledge, skills, and attitudes that allow them to be independent so that they can make useful contributions to the development of the nation and state. According to Law no. 20 of 2003 that: "Education is a conscious and planned effort to create an atmosphere of learning and the learning process so that students actively develop their potential to have religious spiritual activities, self-control, personality, intelligence, noble character, and skills for themselves, the community, the nation, and country". Education has a very important role in the development of the Indonesian people as a whole. Therefore education needs to be developed from various sciences because quality education can improve the quality of a nation. Education is an important part of the national development process that helps increase a country's economic growth. Education is also an investment in developing human resources in increasing skills and abilities as a supporting factor for human efforts to navigate life. One of the knowledge in education that can develop human thinking is mathematical knowledge. According to (Syahrir \& As'ari, 2019) Mathematics is universal 
knowledge that underlies the development of modern technology, has an important role in various disciplines, and develops human thinking. Meanwhile, according to (Kaharuddin \& Hajeniati, 2020; Zetriuslita, Wahyudin, \& Dahlan, 2018) by studying mathematics, students are expected to think logically, analytically, critically, and creatively and are expected to be able to solve all the problems faced, both problems related to lessons. mathematics, as well as those related to everyday life. The 2013 curriculum demands that the learning process of mathematics is directed at learning to find mathematical concepts, learning from real problems by the principles of constructivism learning using a scientific approach (scientific approach) where students gain learning experiences through the $6 \mathrm{M}$ process (observing, asking, exploring or trying, reasoning or concluding, communicating or networking, and creating or making creative work). In line with one of the general objectives of learning mathematics at level Primary and secondary education according to (Arifin \& Aprisal, 2020), namely: understanding mathematical concepts, explaining the relationship between concepts, and applying concepts or algorithms in a flexible, accurate, efficient, and precise way to solve problems.

By the demands of the curriculum, the objectives of learning mathematics, and the facts that occur in school, after the learning process students are expected to understand mathematical concepts so that they can use their abilities in dealing with mathematical problems. According to (Kartika, 2018) in mathematics education, understanding mathematical concepts is an important basis for thinking in solving math problems and real-life problems. So it can be said that understanding the concept is the most important part of learning. This is as stated by (Herawaty, Widada, Nugroho, \& Anggoro, 2019; Magfirah et al., 2019; Sadikin \& Kaharuddin, 2019) that mathematics subjects emphasize concepts, meaning that in studying mathematics students must understand mathematical concepts first to be able to solve problems and be able to apply the learning in the real world. By understanding a concept students can know, explain, describe, compare, differentiate, classify, give examples and not examples, conclude and reexpress an object in its language by being aware of the processes it goes through (Pasnak et al., 2016; Young \& Shtulman, 2020). To observe mathematical concepts, students need to read and interpret information, express their thoughts orally and in writing, listen to others, and think critically about ideas and have the ability to solve problems, both problems in mathematics lessons and problems in everyday life. day.

To improve students' ability to understand mathematical concepts, they must be supported by an appropriate learning approach. One learning approach that can improve conceptual understanding is the ELPSA learning approach which contains five components, namely Experiences, Language, Pictures, Symbols, and Applications. According to 
www.journal.univetbantara.ac.id/index.php/ijimm

(Kaharuddin, 2013) that the ELPSA framework makes an individual develop meaningful mathematical concepts. Meanwhile, according to (Wulandari, 2017), it shows that the component application in ELPSA is a learning activity that seeks to understand the significance of the learning process by applying new knowledge in solving problems in a meaningful context. Furthermore, according to (Syahdan, 2017) learning the ELPSA approach (Experiences, Language, Pictures, Symbols, and Applications) intends to provide free-thinking space for students to seek concepts and problem-solving related to the material taught by teachers at school. Then according to (Lowrie \& Patahuddin, 2015) mathematics aims to make students understand mathematical concepts and their relation to everyday life, have the skills to develop knowledge about natural processes around them, be able to apply various mathematical concepts to explain natural phenomena, and be able to use technology. simple to solve problems found in everyday life.

\section{METHODS}

This research is experimental research conducted at SMP Negeri 6 Makassar. This research aims to determine the effect of the ELPSA learning approach (Experiences, Language, Pictures, Symbols, and Applications) on the understanding of mathematics concepts in grade VIII students of SMP Negeri 6 Makassar. The research design used was the One-Group PretestPosttest Design.

Table 1. Research Design

\begin{tabular}{cccc}
\hline Group & Pretest & Treatment & Posttest \\
\hline $\mathrm{E}$ & $\mathrm{O}_{1}$ & $\mathrm{~T}$ & $\mathrm{O}_{2}$ \\
\hline
\end{tabular}

Source: (Kasiram, 2010)

The population in this study were all class VIII students of SMP Negeri 6 Makassar for the 2019/2020 academic year and then one class was selected as the research sample, namely class VIII who were given treatment using the ELPSA learning approach with the technique Cluster Random Sampling. The reason the researcher chose class VIII as the research sample was because class VIII was a transition period from class VII to class IX and class VIII was a period of students who were always curious and wanted to try new things, during which students had to be given skills and understanding of material concepts to move up to class IX.

The instrument used in this study was the learning implementation observation sheet which aims to determine how well the ELPSA learning approach is implemented and the mathematics concept understanding test refers to the basic competencies and indicators of understanding mathematical concepts which aim to measure students' conceptual understanding skills after the application of the ELPSA learning approach. The indicators of learning outcomes in understanding mathematical concepts in this study are a) The average score for the posttest is 
at least in the high category ( $\mathrm{x}>80$ ); b) The minimum normalized gain average is in the medium category ( $\mathrm{g}>0.3$ ); c) classical completeness of more than $80 \%$; d) The percentage of understanding the concept is at least $80 \%$

The data collection technique in this research is the observation sheet of the implementation of the ELPSA learning approach and the test of understanding the concept of mathematics which is given after the application of the ELPSA learning approach to the eighthgrade students of SMP Negeri 6 Makassar.

The analysis technique in this research is using descriptive statistics and inferential statistics. The descriptive statistical analysis aims to determine the understanding of the material by describing the characteristics of the distribution of students' achievement of mathematics understanding through the ELPSA learning approach. Meanwhile, inferential statistics aims to generalize which includes estimation (estimation) and hypothesis testing based on data obtained from scores on pretest and posttest understanding the concept.

The data obtained from the results of the pretest and posttest were analyzed to determine the increase in students' mathematical understanding abilities. The amount of increase before and after the application of the learning approach used the normalized gain formula.

The formula to determine the increase in learning outcomes is as follows:

$\mathrm{g}=\frac{\mathrm{S}_{\text {pos }}-\mathrm{S}_{\text {pre }}}{\mathrm{S}_{\text {Maks }}-\mathrm{S}_{\text {pre }}}$

Information:

$\mathrm{g}=$ Gainternormalisasi

Spre $=$ Skor pretest

Spos $=$ Skor posttest

Smaks $=$ Skor Maksimum

For normalized gain classification can be seen in the following table.

Table 2. Normalized Gain Classification

\begin{tabular}{cc}
\hline Gain & Classification \\
\hline $\mathrm{g} \leq 0,3$ & Low \\
$0,3<\mathrm{g}<0,7$ & Medium \\
$\mathrm{g} \geq 0,7$ & High \\
\hline
\end{tabular}

Source: (Kaharuddin, 2018)

Criteria used to determine the category of student learning outcomes in this study are presented in the form of a frequency distribution as follows. 
www.journal.univetbantara.ac.id/index.php/ijimm

Table 3. Classification of Concept Understanding Level

\begin{tabular}{cc}
\hline student learning outcomes & classification \\
\hline $0 \leq x \leq 60$ & Very Low \\
$60<x \leq 80$ & Low \\
$80<x \leq 90$ & High \\
$90<x \leq 100$ & Very High \\
\hline
\end{tabular}

Source: (Puspitasari \& Ratu, 2019)

The criteria for a student is said to be complete if the score of concept understanding and problem-solving is more than 80. Meanwhile, classical completeness is achieved when more than $80 \%$ of students in the class are complete. To find out the percentage of each indicator of understanding the concept of mathematics, the following formula is used:

$$
\text { percentage }=\frac{\text { the score for each indicator }}{\text { The ideal score of each indicator }} \times 100 \%
$$

After that, the calculation of the percentage of the ability to understand the concept as a whole is carried out using the following formula:

$$
\text { percentage }=\frac{\text { the total score for each indicator }}{\text { The total ideal score of each indicator }} \times 100 \%
$$

Furthermore, the percentage of students' concept understanding ability is categorized as several levels of understanding using the modified score interpretation criteria by the author.

Table 4. Interpretation Criteria Score Percentage of Concept Understanding

\begin{tabular}{ccc}
\hline No. & Percentage & Level of Understanding \\
\hline 1 & $0 \% \leq x<60 \%$ & Very Low \\
2 & $60 \% \leq x<80 \%$ & Low \\
3 & $80 \% \leq x<90 \%$ & High \\
4 & $90 \% \leq x \leq 100 \%$ & Very High \\
\hline
\end{tabular}

Source: (Ng, Ting, Lam, \& Liu, 2020)

The criteria for assessing the understanding of mathematical concepts are as follows.

\begin{tabular}{|c|c|c|}
\hline Indicator & Information & Score \\
\hline \multirow[t]{6}{*}{ Restate concept } & a. Answer is blank & 0 \\
\hline & b. Cannot restate the concept & 1 \\
\hline & c. Can restate concept but still many mistakes & 2 \\
\hline & d. Can restate concept but not quite right & \\
\hline & e. Be able to restate concepts exactly & 3 \\
\hline & & 4 \\
\hline \multirow{5}{*}{$\begin{array}{l}\text { Provide examples and } \\
\text { non-examples of } \\
\text { concepts }\end{array}$} & a. Answer is blank & 0 \\
\hline & $\begin{array}{l}\text { b. Cannot provide examples and non-examples of a } \\
\text { concept }\end{array}$ & 1 \\
\hline & $\begin{array}{l}\text { c. Can provide examples and non-examples of a concept } \\
\text { but there are still many mistakes }\end{array}$ & 2 \\
\hline & $\begin{array}{l}\text { d. Can provide examples and non-examples of a concept } \\
\text { but are not precise }\end{array}$ & 3 \\
\hline & $\begin{array}{l}\text { e. Can provide examples and non-examples of a concept } \\
\text { appropriately }\end{array}$ & 4 \\
\hline Classify objects & a. Answer is blank & 0 \\
\hline
\end{tabular}

Table 5. Conceptual Understanding Scoring Guidelines 
according to certain properties according to the concept

Presenting concepts in various forms of mathematical representation b. Unable to classify objects according to the concept

c. Can name the properties according to the concept but there are still many mistakes

1

d. Can mention the properties according to the concept but not quite right

e. Can name the properties according to the concept very precisely

a. Answer is blank

b. Cannot present a concept in various forms of mathematical representation

c. Can present a concept in the form of a mathematical representation but there are still many mistakes

d. Can present a concept in the form of a mathematical 3 representation, but not quite right

e. Can present a concept in various forms of mathematical representation appropriately

Source: (Kartika, 2018)

\section{RESULT AND DISCUSSION}

Based on the learning implementation plan (RPP) developed by the researcher by considering the objectives of learning and the steps of the ELPSA learning approach applied to grade VIII students of SMP Negeri 6 Makassar. The lesson plan is made 6 meetings based on the number of sub material. The first meeting discussed the material of two-variable linear equations and two-variable system of linear equations, the second discussed the matter of solving a two-variable system of linear equations using the graph method, the third discussed the matter of solving a two-variable system of linear equations with the substitution method, the fourth discussed the matter of solving a system of two linear equations variables with the elimination method, the fifth discusses the material of solving a system of linear two-variable equations with the mixed method (elimination-substitution), and the sixth discusses the material of making mathematical models and their solutions related to contextual problems.

The format of the Learning Implementation Plan (RPP) is adjusted to the 2013 Curriculum format used in SMP Negeri 6 Makassar. Learning Implementation Plan (RPP) is designed by the learning steps ELPSA approach, namely:

\begin{tabular}{lll}
\hline No & \multicolumn{1}{c}{ Teacher } & \multicolumn{1}{c}{ Students } \\
\hline \multicolumn{1}{c}{ Phase 1: Deliver the purpose of learning and motivate students } \\
\hline 1. $\begin{array}{ll}\text { Preparing students to learn and pray together } & \begin{array}{l}\text { Prepare to study and pray together led by } \\
\text { one of the students } \\
\text { Listening to / paying attention to the } \\
\text { teacher's explanation (Experience) }\end{array} \\
\begin{array}{ll}\text { 2. Inform students about the material to be studied, } \\
\text { namely the SPLDV concept material (Experience) }\end{array} & \begin{array}{l}\text { Listening to the learning objectives } \\
\text { conveyed by the teacher }\end{array} \\
\text { 3. Communicating the learning objectives that will be } \\
\begin{array}{l}\text { achieved by each student. } \\
\text { Exploring students' initial knowledge by asking } \\
\text { questions related to the SPLDV concept (Language, } \\
\text { Pictorial, Symbol) }\end{array}\end{array}$ \\
\hline
\end{tabular}

\begin{tabular}{lll}
\hline \multicolumn{3}{c}{ Core Activity } \\
\hline No & Teacher & Students \\
\hline
\end{tabular}




\section{Phase 2: Presenting information to students}

5. Explaining/providing information as an initial introduction to the SPLDV (Experience)

concept material Paying attention to the teacher's explanation of the SPLDV (concept material experience)

6. Provide opportunities for students to ask questions about the material that has been delivered if anything is not clear (Language, Picture, and Symbol) Ask about the material to the teacher if anything is not clear (Language, Picture, and Symbol) Phase 3: Organizing students in study groups

7. Organizing students into cooperative groups consisting Forming groups based on teacher of 4-6 students heterogeneously

8. Distribute worksheets to students in each group, as well as direct students to complete the worksheets together directions Read/observe the problems presented in the worksheet

Phase 4: Guiding group work and study

9. Guide students to discuss problems in the worksheet with their group friends. (Language, Picture, Symbol, and Application)

Discussing worksheets with group

friends. (Language, Picture, Symbol, and Application)

10 Monitor the course of group discussions and guide the Ask the teacher if there are difficulties. group if anyone is having difficulties (Language) (Language)

\section{Phase 5: Evaluation}

11 Ask several groups to present their work in turn and ask other groups to review their responses. (Language, Picture, Symbol, and Application)

Presenting the results of their group discussions or working on problems on the board. (Language, Picture, Symbol, and Application)

12 Give quizzes to be done independently. (Language, Doing quizzes individually. (Language, Picture, Symbol, and Application)

Phase 6: Giving awards

13 teacher rewards each group with things that can arouse students' enthusiasm and motivation to learn, including praise, applause, or certain items. Picture, Symbol, and Application)

Get an award according to the average score achievement of the group

\begin{tabular}{lll}
\hline \multicolumn{2}{c}{ Final Activity } \\
\hline 14 & $\begin{array}{l}\text { Guide students to conclude the material that has been } \\
\text { studied (Language, Pictorial, Symbol, Application) }\end{array}$ & $\begin{array}{l}\text { Conclude the material that has been } \\
\text { studied (Language, Pictorial, Symbol, } \\
\text { Application) }\end{array}$ \\
15 & $\begin{array}{l}\text { Deliver the title of the sub material will be studied at } \\
\text { the next meeting }\end{array}$ & $\begin{array}{l}\text { Listening to / paying attention to the } \\
\text { explanation from the teacher }\end{array}$ \\
16 & Giving homework to students & Following the teacher's instructions \\
17 & Closing the lesson & Praying before going home \\
\hline
\end{tabular}

The results of the analysis show that the implementation of learning with the application of the ELPSA learning approach at the first meeting is 3.37 in the very well implemented category, the second meeting has obtained an average of 3.58 is in the very well executed category, the third meeting has obtained an average of 3, 68 were in the very well executed category, the fourth meeting has obtained an average of 3.63 was in the very well executed category, the fifth meeting has obtained an average of 3.63 was in the very well executed category, and the sixth meeting was obtained on average an average of 3.68 is in the very well performed category. Based on this description, it can be concluded that in the learning process by applying the ELPSA learning approach the teacher's ability to manage learning for 6 meetings was carried out very well. 
www.journal.univetbantara.ac.id/index.php/ijimm

Furthermore, the learning outcomes of students' understanding of mathematical concepts after applying the ELPSA learning approach to class VIII students of SMP Negeri 6 Makassar.

Table 6. Recapitulation of Student Concept Understanding Learning Outcomes Class VIII.9 SMP Negeri 6 Makassar

\begin{tabular}{ccc}
\hline Statistik & Pretest_PK & Posttest_PK \\
\hline Sample & 33 & 33 \\
Mean & 40.9697 & 91.3333 \\
Med & 40.0000 & 92.0000 \\
Mod & $25.00^{\mathrm{a}}$ & 95.00 \\
Deviation Standart & 11.88614 & 5.59948 \\
Variance & 141.280 & 31.354 \\
Skewness & 0.223 & -0.318 \\
Ranges & 35.00 & 20.00 \\
Max & 25.00 & 80.00 \\
Min & 60.00 & 100.00 \\
\hline
\end{tabular}

Based on the table above, it can be seen that the mean posttest understanding of students' concepts is 91.33 . This shows that in general, the scores posttest are in the very high category, thus there is an increase in the mean value of students from pretest to posttest (from very low to very high categories). The median score of the posttest students was 92.00 indicating that there were about $50 \%$ of the students who obtained the highest score of 92.00 or the lowest score of 92.00. The mode score of 95.00 indicates that the post-test understanding of the concept of students with the greatest frequency is 95.00 . Based on the slope coefficient of -0.31 and paying attention to the mean, median and mode values, it can be said that in general the results of the posttest students' understanding of the concept are above the average with a very high category.

Table 7. Classification of Normalized Gain Understanding Student Concepts

Class VIII.9 SMP Negeri 6 Makassar

\begin{tabular}{cccc}
\hline Gain & Classification & Student & Percentace(\%) \\
\hline $\mathrm{g} \geq 0,7$ & Tinggi & 32 & 97 \\
$0,3<\mathrm{g}<0,7$ & Sedang & 1 & 3 \\
$\mathrm{~g} \leq 0,3$ & Rendah & 0 & 0 \\
\hline Jumlah & & 33 & 100 \\
\hline
\end{tabular}

From the table, it can be seen that 32 students are in the high category with a percentage of $97 \%$ and 1 student is in the medium category with a percentage of $3 \%$. None of the students scored in the low category. This indicates that the students' conceptual understanding increases after the ELPSA learning approaches are applied in class VIII.9 SMP Negeri 6 Makassar is in the high category with a percentage of $97 \%$. Based on the description above, it can be concluded that descriptively the increase in students' understanding of concepts after implementing the 
www.journal.univetbantara.ac.id/index.php/ijimm

ELPSA learning approach the material of the two-variable linear equation system in class VIII.9 SMP Negeri 6 Makassar is in the high category with a percentage of $97 \%$.

Table 8. Percentage of Student Concept Understanding scores per indicator

\begin{tabular}{clccc}
\hline No. & \multicolumn{1}{c}{ Indicators } & $\begin{array}{c}\text { Percentage } \\
(\%)\end{array}$ & Classification \\
\hline 1 & Restate concept. & 93.43 & Very High \\
2 & Provide examples and non-concept examples. & 92,93 & Very High \\
3 & $\begin{array}{l}\text { Classify objects according to certain properties. } \\
4\end{array}$ & $\begin{array}{l}\text { Presenting concepts in various forms of mathematical } \\
\text { representation. }\end{array}$ & 91,08 & $\begin{array}{c}\text { Very High } \\
\text { Mean }\end{array}$ \\
\hline
\end{tabular}

Based on the table, the data analysis that has been done shows that the score of students who can restate a concept well reaches $93.43 \%$ in the category Very high, the score of students who can provide examples and non-examples of the concept well reaches $92.93 \%$ with the category. Very high, the score of students who can classify objects according to certain properties according to the concept well reaches $91.08 \%$ with the category Very high, and the score of students who can present concepts in various forms of mathematical representation reaches $89.20 \%$ with category High. So it can be concluded that descriptively the students' ability to understand mathematical concepts in the material of the two-variable linear equation system for class VIII.9 SMP Negeri 6 Makassar is categorized as very high with the overall percentage of each indicator of concept understanding reaching $91.66 \%$.

Based on the research results it has been described that the results of students' understanding of mathematical concepts after applying the ELPSA learning approach are increasing. The increase in students' understanding of mathematical concepts is the effect of the application of the ELPSA learning approach. So, in this discussion, the effect of the components of the ELPSA learning approach on each indicator of conceptual understanding is described. The ELPSA approach which includes experiences, language, pictures, symbols, and application affects every indicator of concept understanding, namely:

\section{a) Experiences $(\mathrm{E})$}

Experiences are learning activities that explain or bring up previous experiences that students have and relate them to new knowledge and experiences or information that will be obtained or learned. At this stage, students can restate a simple concept based on experience and knowledge that has been studied or experienced contextually, namely: being able to name the object, model, or shape of the object related to the subject matter of the two-variable linear equation system. However, at this stage, it is still weak in terms of students' ability to provide 
examples and not examples of a concept, classify objects according to certain properties, and present concepts in various forms of mathematical representations.

According to (Arifin \& Aprisal, 2020; Baharun, 2018) experiences include how students have used mathematics so far, what concepts they know, how they can obtain information, and how mathematics has been experienced by students both inside and outside the classroom. Knowledge is awakened when students try to organize their experiences according to their cognitive structures.

\section{b) Language (L)}

Language (language development) is a learning activity that actively develops certain mathematical languages so that the learners interpret them. It is important for teachers to model correct language and students need to be encouraged to use clear language in describing their understanding to the teacher and their peers. At this stage students can restate a concept and mention examples and not examples of a concept, namely: when the teacher delivers or explains the material and mentions parables or examples in clear language and is easily understood by students, therefore students can restate a concept and citing examples and not examples of twovariable linear equation systems in their language using clear language in describing their understanding to the teacher and their peers.

According to (Herawaty et al., 2019) language is used to encourage understanding. In mathematics, the language of mathematics can be general or specific and is needed to present mathematical ideas. It can happen that students do not understand a mathematical concept not because the concept is too difficult for them but because the teacher who presents it uses words or sentences that the students cannot understand.

\section{c) Pictures $(\mathrm{P})$}

Pictures (image representations) are learning activities that provide experiences about mathematical concepts in the form of pictures. At this stage, students can restate a concept, be able to provide examples and non-examples, be able to classify objects according to certain properties and be able to present concepts in various forms of mathematical representations of two-variable linear equation systems based on pictures, graphs, diagrams, tables, and so forth.

According to (Baron, 2019) that visualization is important in mathematical thinking that can be realized in the form of shadow(image)image on the paper or the display of technology. Image representation (component "P" of ELPSA) can be used to stimulate students to think mathematically, namely what kind of image or visualization is more effective in helping 
students understand mathematics which can be a stepping stone for students to arrive at the "S" component of ELPSA.

d) Symbols (S)

Symbols (symbol representation) are learning activities that can change or make the transition from image representation to symbol representation. Mathematical concepts contain many symbols, either formulas or abstract statements. At this stage, students can restate a concept, be able to provide examples and non-examples, be able to classify objects according to certain properties, and be able to present concepts in various forms of mathematical representations of two-variable linear equation systems based on symbols which are transitions from image representations.

According to (Wulandari, 2017; Young \& Shtulman, 2020) asserts that symbols in ELPSA are a more general experience and are the result of generalizations. A series of symbols in mathematics can take the form of a mathematical model. Symbols in mathematics can deliver students' knowledge to find solutions and apply formulas in solving math problems.

\section{e) Application (I)}

Application (application of knowledge) is a learning activity that seeks to understand the significance of the learning process by applying new knowledge in solving problems in a meaningful context. At this stage, students can restate a concept, be able to provide examples and non-examples, be able to classify objects according to certain properties, and be able to present concepts in various forms of mathematical representations of two-variable linear equation systems based on knowledge obtained from all components or steps. -the learning steps of the ELPSA approach, namely, experiences, language, pictures, symbols, and application.

According to (Lowrie \& Jorgensen, 2011) that the application stage describes how the knowledge and understanding of concepts that have been obtained can be applied in various situations. Thus, in the application component students use the ability to understand concepts in solving a problem.

In general, it can be said that the application of the ELPSA learning approach is an active process in which students build their ways and understand things through independent processes and interact socially with other students, and can construct their ways of understanding things through individual thought processes and social interactions. In ELPSA learning, students learn more systematically and are oriented towards finding concepts from their knowledge experience and can involve students' activeness directly in constructing their 
$w w w$.journal.univetbantara.ac.id/index.php/ijimm

knowledge in the process of understanding mathematical concepts, as well as providing free space for students to think about concepts and solving related problems. with the material taught by the teacher at school.

\section{CONCLUSION}

This study concludes that the application of the ELPSA learning approach can improve the understanding of the concept of the material of the two-variable linear equation system in class VIII students of SMP Negeri 6 Makassar. ELPSA learning which includes experiences, language, pictures, symbols, and application affects every indicator of concept understanding, namely indicator I (93.43\%) students can restate a concept in the experiences and language stages, indicator II (92.93\%) able to provide examples and non-examples in a concept at the language and pictures stage, indicator III (91.08\%) students can classify objects according to certain characteristics according to the concept at the pictures and symbols stage, indicator IV $(89,20 \%)$ students can present the concept in various forms of mathematical representation at the symbols and application stages.

\section{REFERENCES}

Arifin, S., \& Aprisal, A. (2020). Analisis Tingkat Pemahaman Konsep Statistika Mahasiswa Calon Guru Menggunakan Two Tier Test Berbasis Online. Delta: Jurnal Ilmiah Pendidikan Matematika, 8(2), 201-208.

Baharun, H. (2018). Curriculum Developmnent Trouht Creative Lesson Plan. Jurnal Cendikia, 16(1), 43.

Baron, J. (2019). Actively open-minded thinking in politics. Cognition, 188(August), 8-18. https://doi.org/10.1016/j.cognition.2018.10.004

Herawaty, D., Widada, W., Nugroho, K. U. Z., \& Anggoro, A. F. D. (2019). The Improvement of the Understanding of Mathematical Concepts through the Implementation of Realistic Mathematics Learning and Ethnomathematics. 295(ICETeP 2018), 21-25. https://doi.org/10.2991/icetep18.2019 .6

Kaharuddin, A. (2013). Effectiveness Comparative Of Scientific Approach ELPSA And Open-Ended Setting Cooperative STAD Types Of Mathematics Learning At VII Class SMP Negeri Of A Accreditation In Makassar. Daya Matematis: Jurnal Inovasi Pendidikan Matematika, 1(1), 29-44.

Kaharuddin, A. (2018). Keefektifan Model Make A Match dalam Pembelajaran Matematika Siswa Kelas VI Sekolah Dasar di Kecamatan Marioriwawo. Madrasah: Jurnal Pendidikan dan Pembelajaran Dasar, 11(1), 13-23.

Kaharuddin, A., \& Hajeniati, N. (2020). The Effect Of Combination Of Number Head Together And Two Stay Two Stray Learning Models On Mathematical Learning Outcomes And. International Journal of Educational Best Practices (IJEBP), 4(2), 78-87. https://doi.org/10.32581/ijebp.v4n2.p78-87

Kartika, Y. (2018). Analisis Kemampuan Pemahaman Konsep Matematis Peserta Didik Kelas Vii Smp Pada Materi Bentuk Aljabar. Jurnal Pendidikan Tambusai, 2(4), 777-785.

Kasiram, M. (2010). Metodologi penelitian: Kualitatif-kuantitatif.

Lowrie, T., \& Jorgensen, R. (2011). Gender differences in students' mathematics game playing. Computers and Education, 57(4), 2244-2248. https://doi.org/10.1016/j.compedu.2011.06.010

Lowrie, T., \& Patahuddin, S. M. (2015). ELPSA â Kerangka Kerja untuk Merancang Pembelajaran Matematika. Didaktik Matematika, 2(1), 94-108.

Magfirah, I., Kaharuddin, A., \& Wangse, F. (2015). Efektifitas Model Pembelajaran Kooperatif Tipe Think Pair Share (TPS) Dengan Pendekatan Open-Ended Dalam Pembelajaran Matematika Materi Segi Empat Siswa Kelas VIII SMPN 14 Buru. Matematika, 104.

Ng, O. L., Ting, F., Lam, W. H., \& Liu, M. (2020). Active Learning in Undergraduate Mathematics 
Tutorials Via Cooperative Problem-Based Learning and Peer Assessment with Interactive Online Whiteboards. Asia-Pacific Education Researcher, 29(3), 285-294. https://doi.org/10.1007/s40299019-00481-1

Pasnak, R., Schmerold, K. L., Robinson, M. F., Gadzichowski, K. M., Bock, A. M., O’Brien, S. E., ... Gallington, D. A. (2016). Understanding number sequences leads to understanding mathematics concepts. Journal of Educational Research, 109(6), 640-646. https://doi.org/10.1080/00220671.2015.1020911

Puspitasari, \& Ratu, N. (2019). Deskripsi Pemahaman Konsep Siswa dalam Menyelesaikan Soal PISA pada Konten Space and Shape Mosharafa: Jurnal Pendidikan Matematika Mosharafa: Jurnal Pendidikan Matematika. 8, 155-166.

Sadikin, S., \& Kaharuddin, A. (2019). Identifikasi Kemampuan Komunikasi Matematika Ditinjau Dari Self-concept Matematis Dan Gender.

Syahdan, S. (2017). the Effectiveness of the Implementation of Experience, Language, Pictorial, Symbol, and Application (Elpsa) in Mathematics Learning Based on Bruners Theory To Class Vii Students At SMPN 29 in Makassar. Jurnal Daya Matematis, 4(2), 192. https://doi.org/10.26858/jds.v4i2.2898

Syahrir, N. A., \& As'ari, A. R. (2019). The Influence of Teacher's Gestures to Strengthening the Understanding of Mathematics Students. International Journal of Insights for Mathematics Teaching, 02(1), 75-84.

Umar, U., Kaharuddin, A., Fauzi, A., Widodo, A., Radiusman, R., \& Erfan, M. (2020, August). A Comparative Study on Critical Thinking of Mathematical Problem Solving Using Problem Based Learning and Direct Intruction. In 1st Annual Conference on Education and Social Sciences (ACCESS 2019) (pp. 314-316). Atlantis Press.

Wulandari, A. A. (2017). Implementasi Worksheet ELPSA Pada Pembelajaran Relasi Rekurensi. JIMP (Jurnal Ilmiah Pendidikan Matematika), 6(1), 60-67.

Young, A. G., \& Shtulman, A. (2020). Children's Cognitive Reflection Predicts Conceptual Understanding in Science and Mathematics. Psychological Science, (1), 6-8. https://doi.org/10.1177/0956797620954449

Zetriuslita, Z., Wahyudin, W., \& Dahlan, J. A. (2018). Association Among Mathematical Critical Thinking Skill, Communication, and Curiosity Attitude As the Impact of Problem-Based Learning and Cognitive Conflict Strategy (Pblccs) in Number Theory Course. Infinity Journal, 7(1), 15. https://doi.org/10.22460/infinity.v7i1.p15-24 